This Accepted Author Manuscript is copyrighted and published by Elsevier. It is posted here by agreement between Elsevier and University of Brasilia. Changes resulting from the publishing process - such as editing, corrections, structural formatting, and other quality control mechanisms - may not be reflected in this version of the text. The definitive version of the text was subsequently published in [Tissue and Cell, Volume 36, Issue 3, June 2004, Pages 171-180, doi:10.1016/j.tice.2004.01.002].You may download, copy and otherwise use the AAM for noncommercial purposes provided that your license is limited by the following restrictions:

(1) You may use this AAM for non-commercial purposes only under the terms of the CC-BY-NCND license.

(2) The integrity of the work and identification of the author, copyright owner, and publisher must be preserved in any copy.

(3) You must attribute this AAM in the following format: [agreed attribution language, including link to CC BY-NC-ND license + Digital Object Identifier link to the published journal article on Elsevier's ScienceDirect ${ }^{\circledR}$ platform].

Este Manuscrito do Autor Aceito para Publicação (AAM) é protegido por direitos autorais e publicado pela Elsevier. Ele esta disponível neste Repositório, por acordo entre a Elsevier e a Universidade de Brasília. As alterações decorrentes do processo de publicação - como a edição, correção, formatação estrutural, e outros mecanismos de controle de qualidade - não estão refletidas nesta versão do texto. A versão definitiva do texto foi posteriormente publicado em [Tissue and Cell, Volume 36, Número 3, Junho de 2004, Paginas 171-180, doi:10.1016/j.tice.2004.01.002]. Você pode baixar, copiar e utilizar de outra forma o AAM para fins não comerciais, desde que sua licença seja limitada pelas seguintes restrições:

(1) Você pode usar este AAM para fins não comerciais apenas sob os termos da licença CC- BYNC-ND.

(2) A integridade do trabalho e identificação do autor, detentor dos direitos autorais e editor deve ser preservado em qualquer cópia.

(3) Tem de atribuir este AAM no seguinte formato: [acordo na linguagem atribuída, incluindo o link para CC BY-NC-ND licença Digital + DOI do artigo publicado na revista Elsevier ScienceDirect ${ }^{\circledR}$ da plataforma]. 


\title{
Morphological characterization of Anticarsia gemmatalis $M$ nucleopolyhedrovirus infection in haemocytes from its natural larval host, the velvet bean caterpillar Anticarsia gemmatalis (Hübner) (Lepidoptera: Noctuidae)
}

\author{
E.B Silveira \\ B.A Cordeiro \\ B.M Ribeirob \\ S.N Báo
}

\begin{abstract}
For a better understanding of virus xhost interactions, transmission electron microscopy was used to characterize the intrahaemocoelic infection of Anticarsia gemmatalis larval haemocytes by $A$. gemmatalis $M$ nucleopolyhedrovirus (AgMNPV). At $12 \mathrm{~h}$ post-infection ( $\mathrm{h}$ p.i.), we observed nuclear hypertrophy, budded virus assembling, and protrusion towards the cytoplasm, virion envelopment, and accumulation of fibrillar aggregates in the cytoplasm. Around $24 \mathrm{~h}$ p.i., fibrillar aggregates also appeared inside nuclei of infected cells. By $48 \mathrm{~h}$ p.i., virogenic stroma and polyhedra were visualised in nuclei and at $72 \mathrm{~h}$ p.i., widespread infection in haemocytes was observed. Cell remnants and free polyhedra were phagocytosed by granular haemocyte 1 and plasmatocytes. Entire cells were phagocytosed only by plasmatocytes. Necrosis of infected cells was quite common, suggesting a putative cytotoxic response. Granular haemocyte 1 presented a more exuberant protrusion of budded viruses in comparison to other haemocytes. All types of haemocytes were shown to be infected, and the intense virus replication in some of these cells reveals the importance of haemolymph for AgMNPV spread in its natural host, a critical factor for permissiveness.
\end{abstract}

Keywords: Anticarsia gemmatalis; AgMNPV; Baculovirus; Haemocytes; Lepidoptera; Ultrastructure

\section{Introduction}

The baculovirus Anticarsia gemmatalis M nucleopolyhedrovirus (AgMNPV) has been used during the last 23 years in Brazil to control the velvet bean caterpillar A. gemmatalis (Hübner), representing important reduction in production costs and environmental damages caused by chemical pesticides in soybean (Glycine max) crops ( Ribeiro et al., 1998 and Moscardi, 1999). Efforts have been made to explore AgMNPV molecular biology and host interaction with the attempt to enhance the economical and scientific application of this virus ( Pombo et al., 1998, Matos et al., 1999, Silveira et al., 1999, Castro and Ribeiro, 2001, Ribeiro et al., 2001, Rodrigues et al., 2001, Razuck et al., 2002 and Pinedo et al., 2003).

AgMNPV is a rod-shaped, enveloped virus with circular, double-stranded, 133-kbp DNA genome, pathogenic to lepidopterans ( Johnson and Maruniak, 1989 and Grasela and McIntosh, 1998). Like other baculoviruses from the Nucleopolyhedrovirus genus, it presents two phenotypes: budded viruses (BVs), which establish systemic infection; and occlusion- 
derived viruses (ODVs), immersed in a proteinaceous matrix, constituting occlusion bodies (OBs) or polyhedra. OBs are stable in environment and are responsible for the spread of insectto-insect infection ( Volkman and Keddie, 1990).

Infected cells show a typical cytopathology related to viral morphogenesis, generally characterized by changes in cell shape and size, nuclear hypertrophy and chromatin reorganisation, virions assembly and envelopment at the nucleus, virogenic stroma development, accumulation of fibrillar aggregates and polyhedra assembly at the nucleus (reviewed by Williams and Faulkner, 1997).

The haemocytes of insects comprise a complex of cell types that circulates in haemolymph being involved in defence responses as wound repair, phagocytosis, nodulation, encapsulation, coagulation, synthesis and secretion of immunologic factors (reviewed by Lavine and Strand, 2002).

Haemolymph has been shown to contribute to baculovirus dissemination in permissive hosts (Granados and Lawler, 1981, Washburn et al., 1995 and Barrett et al., 1998). However, haemocyte resistance, apoptosis or an effective cellular immune response against infection may restrict the replication of NPVs in specific virus-host combinations (Washburn et al., 1996, Washburn et al., 2000, Trudeau et al., 2001, Clark and Clem, 2002, Clark and Clem, 2003a and Zhang et al., 2002).

Despite the crucial importance of haemocytes for the progression of baculovirus infection, detailed information about interactions among these viruses and the different types of haemocytes remains scarce. In this study, we identified the A. gemmatalis haemocyte types that are susceptible to AgMNPV, described the morphological alterations, viral morphogenesis events, and putative immune responses generated during infection by using transmission electron microscopy.

\section{Materials and methods}

\subsection{Insects and viruses}

Anticarsia gemmatalis larvae were provided by Embrapa-Recursos Genéticos e Biotecnologia and Embrapa-Soja and reared on artificial diet at room temperature $\left(25^{\circ} \mathrm{C}\right)$. The molts were monitored, and 4th instar larvae (between 0 and $24 \mathrm{~h}$ after molt) were used. AgMNPV isolate 2D ( Sieburth and Maruniak, 1988) was propagated in BTI-Tn-5B1-4 (Tn-5B) cells ( Granados et al., 1994) and maintained in TC-100 medium (GIBCO-BRL Life Technologies, 
Grand Island, NY, USA) supplemented with $10 \%$ fetal bovine serum at $27^{\circ} \mathrm{C}$. The inoculum was titered by the TCID50 method, following the protocol described by O'Reilly et al. (1992).

\subsection{Inoculation and haemolymph extraction}

Approximately $10-20 \mu \mathrm{l}$ of viral inoculum (108 pfu/ml) were injected in each larva directly to the haemocoel, by using an insulin microsyringe. Controls were obtained by the inoculation of an equal volume of TC-100 medium. After 12, 24, 48 and $72 \mathrm{~h}$ of inoculation, the haemolymph was collected from a punctured proleg.

\subsection{Transmission electron microscopy}

For transmission electron microscopy (TEM), the haemolymph was fixed for $30 \mathrm{~min}$ ( $2 \%$ glutaraldehyde, $2 \%$ paraformaldehyde in $0.1 \mathrm{M}$ sodium cacodylate buffer, $\mathrm{pH} 7.4$, with $5 \%$ sucrose). After fixation, it was centrifuged at $750 \times \mathrm{g}$ for $5 \mathrm{~min}$, the pellet was washed in the same buffer, post-fixed ( $1 \%$ osmium tetroxide, $0.8 \%$ potassium ferricyanide in the same buffer), contrasted in block with $0.5 \%$ uranyl acetate, dehydrated in acetone and embedded in Spurr's resin. The ultrathin sections were contrasted with uranyl acetate/lead citrate and observed in a TEM JEOL $100 \mathrm{C}$ and JEOL 1011 at $80 \mathrm{kV}$.

\subsection{Haemocytes identification}

Larval A. gemmatalis haemocytes types were identified by structural and ultrastructural characteristics described previously ( Silveira et al., 2003).

\section{Results}

\subsection{Insect behaviour after intrahaemocoelic injection}

The group of larvae injected with viral inoculum presented typical characteristics of baculovirus infection. Their feeding was diminished, their movements were reduced and the molt to 5 th instar was not completed. Their colour became whitish around $48 \mathrm{~h} \mathrm{p.i.} \mathrm{and} \mathrm{they}$ started to die around $96 \mathrm{~h}$ p.i. The control group continued feeding, and moving normally, completing the molt to 5 th instar around $48 \mathrm{~h} \mathrm{p.i.,} \mathrm{with} \mathrm{some} \mathrm{of} \mathrm{them} \mathrm{molting} \mathrm{to} \mathrm{6th} \mathrm{instar} \mathrm{at}$ 72 h p.i. 


\subsection{Transmission electron microscopy}

Six haemocytes types were recognised in A gemmatalis larvae based on structural and ultrastructural characteristics, as described previously ( Silveira et al., 2003). They were prohaemocytes (pr), plasmatocytes (pl), granular haemocytes type 1 (gh1), granular haemocytes type 2 (gh2), oenocytoids (oe) and spherulocytes (sph).

Prohaemocytes (pr) are the smallest cells, generally spherical, with a smooth surface and a high ratio nucleus/cytoplasm. Plasmatocytes ( $\mathrm{pl}$ ) can be fusiform, round or oval. Their surfaces present many membrane projections and peripheral vacuoles. The nucleus is often bilobate; the cytoplasm is dense, with many mitochondria, free ribosomes, rough endoplasmic reticulum and Golgi complexes. Granular haemocytes type 1 (gh1) are spherical and characterised by three types of granules: structured granules, containing material arranged in a highly ordered lattice; unstructured granules, containing flocculent material; and dense granules, presenting a homogeneous and moderately electron-dense content. The rough endoplasmic reticulum is well developed, with dilated cisternae. Granular haemocytes type 2 (gh2) can be spherical or somewhat elongated with large and numerous dense granules. Oenocytoids (oe) are typically round, with a small and eccentric nucleus, and the cytoplasm is characteristically homogeneous, poor in membranous organelles and rich in free ribosomes. Mitochondria are concentrated in the cellular periphery. Spherulocytes (sph) are characterised by large vesicles (spherules) that occupy almost the entire cytoplasm, and contain a granular and symmetrical material that can be arranged in concentric layers.

All types of haemocytes were shown to be susceptible to AgMNPV intrahaemocoelic infection. Despite the severe morphological alterations induced by viral infection, some cells still exhibited characteristic ultrastructure, which made cell identification possible.

At $12 \mathrm{~h}$ p.i., there were distinct nuclear alterations, as hypertrophy, a slight folding of the nuclear envelope, heterochromatin dislocation to the nuclear periphery, accumulation of electron-dense material, and virion assembly (Fig. 1A-D). Some virions were seen protruding towards the cytoplasm, covered by a portion of the nuclear envelope, and also, budding to the exterior, covered by the plasma membrane (Fig. 1B-D). Besides virion assembly, we also visualized virion envelopment (Fig. 1B-D). Fibrillar aggregates, probably of the viral P10 protein, and networks of endomembranes were observed in the cytoplasm (Fig. 1D and E). 


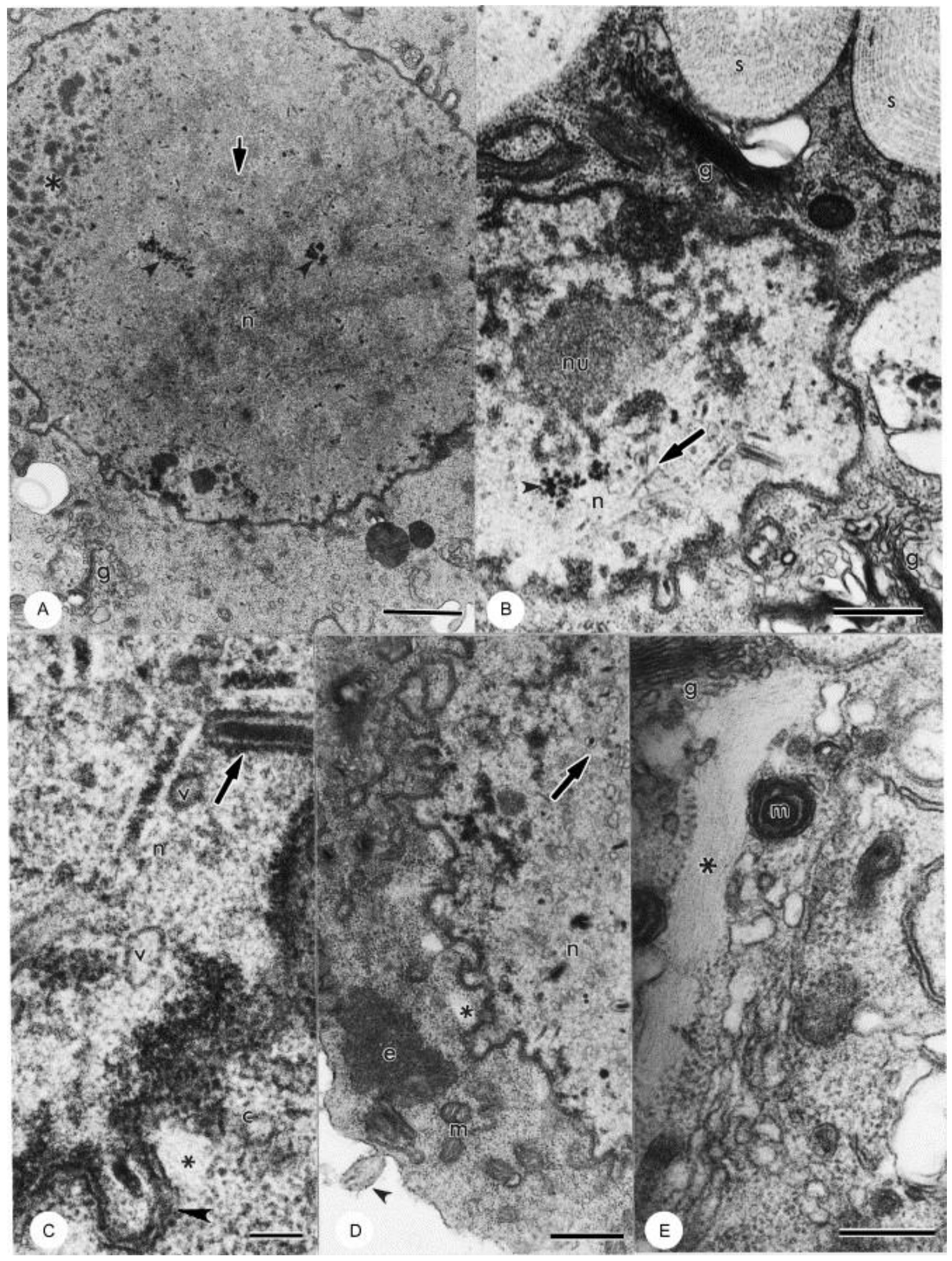

Fig. 1. Transmission electron micrographs of Anticarsia gemmatalis haemocytes $12 \mathrm{~h}$ p.i. with AgMNPV. (A) Oenocytoid presenting a hypertrophied nucleus $(n)$ with early signs of infection as virions assembly (arrow), electron-dense accumulations (arrowheads) and peripheral heterochromatin (*); g, Golgi. Bar 1 $\mu \mathrm{m}$. (B) Spherulocyte presenting virions envelopment (arrow). Arrowhead, electron-dense accumulations; g, Golgi; $n$, nucleus; nu, nucleolus; s, spherule. Bar $0.5 \mu \mathrm{m}$. (C) High-magnified detail from the previous picture, where virion envelopment (arrow), virion budding (arrowhead) from the nucleus $(n)$ to the cytoplasm (c), fibrillar aggregate $(*)$ and nuclear membranous vesicles $(v)$ can be better noted. Bar $0.1 \mu \mathrm{m}$. (D) Putative prohaemocyte or plasmatocyte presenting virion budding towards the exterior media (arrowhead) and an endomembrane network (e) besides viral envelopment 
(arrow) and fibrillar aggregate $(*) ; \mathrm{m}$, mitochondria; $\mathrm{n}$, nucleus. Bar $0.5 \mu \mathrm{m}$. (E) Plasmatocyte showing a more extensive fibrillar aggregate (*); g, Golgi; m, mitochondria. Bar $0.25 \mu \mathrm{m}$.

At $24 \mathrm{~h}$ p.i., multiple envelopment of virions as well as virions budding to the cytoplasm increased (Fig. 2A and B). The fibrillar aggregates became larger, with nuclear occurrence (not shown), in addition to cytoplasmic accumulation (Fig. 2B). At this time of infection, many gh1 presented a variable number of putative phagosomes and phagolysosomes, which were filled with numerous membranous profiles, intact ribosomes and partially digested material with a flocculent aspect (Fig. 2C).

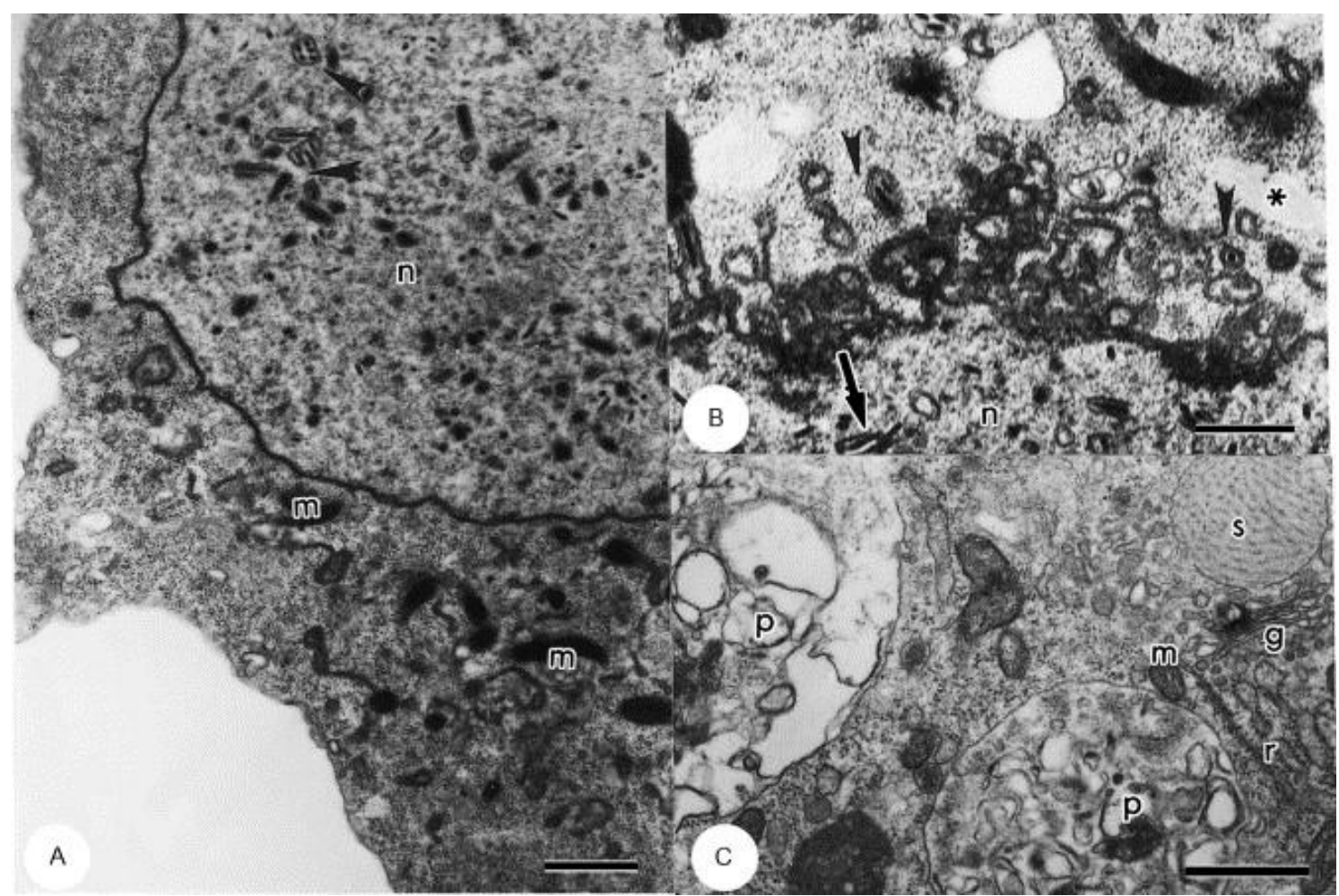

Fig. 2. Transmission electron micrographs of Anticarsia gemmatalis haemocytes $24 \mathrm{~h}$ p.i. with AgMNPV. (A) Putative prohaemocyte or plasmatocyte presenting early signs of infection. Arrowheads, virion envelopment; $m$, mitochondria; $n$, nucleus. (B) Putative prohaemocyte or plasmatocyte with an intense viral budding trough extensive folds of the nuclear envelope (arrowheads). Arrow, virion envelopment; fibrillar aggregate $(*)$; n, nucleus. (C) Granular haemocyte 1 cytoplasm containing phagosomes filled with cell remnants (p); g, Golgi; $m$, mitochondria; $r$, rough endoplasmic reticulum; s, structured granule. Bars $0.5 \mu \mathrm{m}$.

At $48 \mathrm{~h}$ p.i., mature virogenic stroma was observed (Fig. 3A and D) and the assembly of polyhedra in cell nuclei became more frequent (Fig. 3C). Plasmatocytes (pl) as well as gh1 presented a great number of putative phagosomes and phagolysosomes. Besides cell remnants, as observed at $24 \mathrm{~h}$ p.i., these organelles contained also viral particles and free polyhedra (Fig. 3 and Fig. 4). Necrosis of some infected cells, specially the ones containing a mature virogenic stroma, was common. Necrosis was characterized by expansion and rupture of mitochondria, and loss of nuclear and cytoplasmic contents, which gives a general electron lucent aspect for the cell (Fig. 3D). 


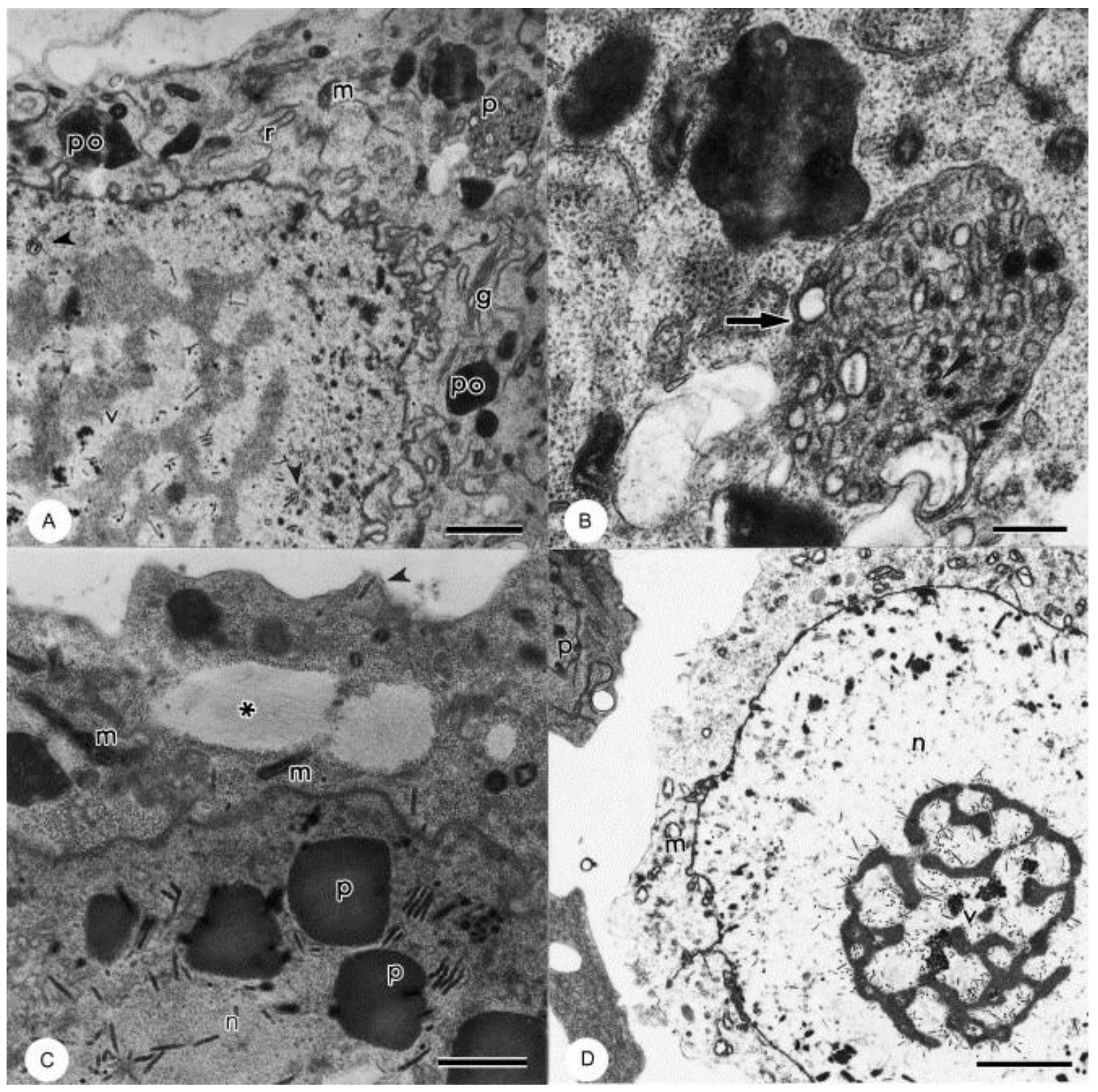

Fig. 3. Transmission electron micrographs of Anticarsia gemmatalis haemocytes $48 \mathrm{~h}$ p.i. with AgMNPV. (A) Infected plasmatocyte presenting a phagosome filled with cell remnants ( $p$ ) and phagosomes containing polyhedra (po) in its cytoplasm, and a well-developed virogenic stroma (v). Arrowheads, virions envelopment; g, Golgi, m, mitochondria; r, rough endoplasmic reticulum. Bar $1 \mu \mathrm{m}$. (B) Highmagnified detail from the previous picture showing a phagosome (arrow) containing infected cell remnants presenting enveloped viral particles (arrowhead). Bar $0.25 \mu \mathrm{m}$. (C) Putative prohaemocyte or plasmatocyte presenting polyhedra $(p)$ into the nucleus $(n)$ and viral budding the plasma membrane (arrowhead). Fibrillar aggregate $(*) ; \mathrm{m}$, mitochondria. Bar $0.5 \mu \mathrm{m}$. (D) Not identified haemocyte in necrosis presenting a mature virogenic stroma $(v)$ into the nucleus $(n)$ and vacuolated mitochondria $(m)$; p; plasmatocyte. Bar $2 \mu \mathrm{m}$. 


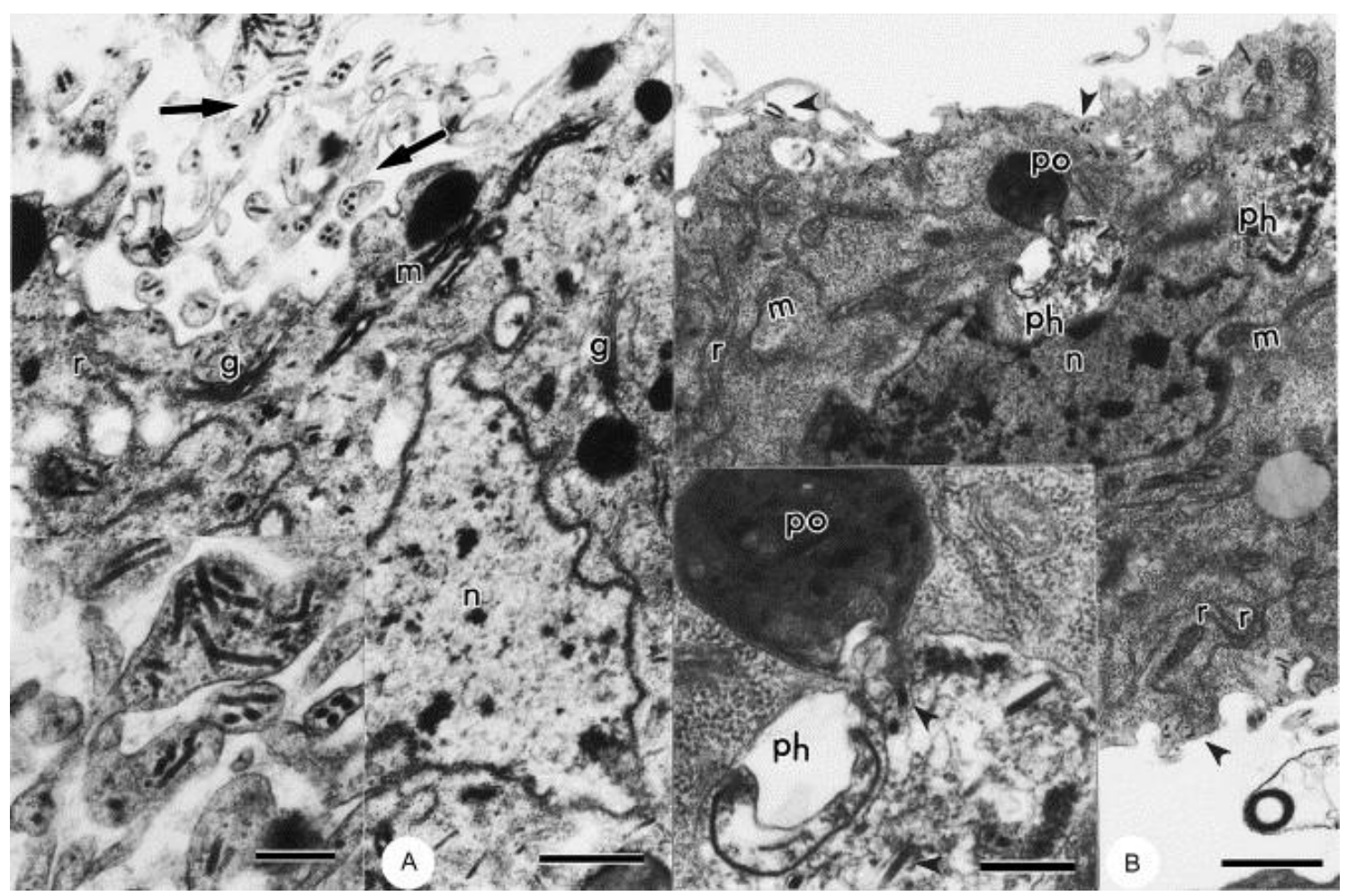

Fig. 4. Transmission electron micrographs of Anticarsia gemmatalis granular haemocyte $148 \mathrm{~h}$ p.i. with AgMNPV. (A) Extensive surface projections containing viral particles (arrows); g, Golgi; m, mitochondria; $\mathrm{n}$, nucleus; $r$, rough endoplasmic reticulum. Bar $0.5 \mu \mathrm{m}$. Inset: high-magnified detail of surface projections. Bar $0.25 \mu \mathrm{m}$. (B) Apparently non-infected cell showing numerous virions in its cytoplasm and surface projections (arrowheads). A phagosome containing a polyhedra (po) is in close contact with a phagolysosome (ph); $\mathrm{n}$, nucleus; $\mathrm{m}$, mitochondria; $r$, rough endoplasmic reticulum. Bar $1 \mu \mathrm{m}$. Inset: high-magnified detail of the fusion between the phagosome (po) and the phagolysosome (ph), which presents digestion remnants and apparently intact enveloped virions (arrowheads). Bar $0.25 \mu \mathrm{m}$.

At late times post-infection, a peculiar characteristic of gh1 was observed. Great numbers of viral particles at the periphery of the cytoplasm or in numerous cytoplasmic projections-filopodia were observed (Fig. 4A). This was observed in infected cells (Fig. 6A), as well as in those with an apparently non-infected nucleus, but containing in their cytoplasm phagocytosed polyhedra and putative phagolysosomes, which were filled with flocculent, electron-dense material and some intact enveloped virions (Fig. 4B).

At $72 \mathrm{~h}$ p.i., there was abundance of infected haemocytes, which presented early and late symptoms of infection, and most cells presented polyhedra in their nuclei and larger fibrillar aggregates (Fig. 5A and B). At that time of infection, it was possible to observe numerous free BVs in the extracellular space (Fig. 5C). 


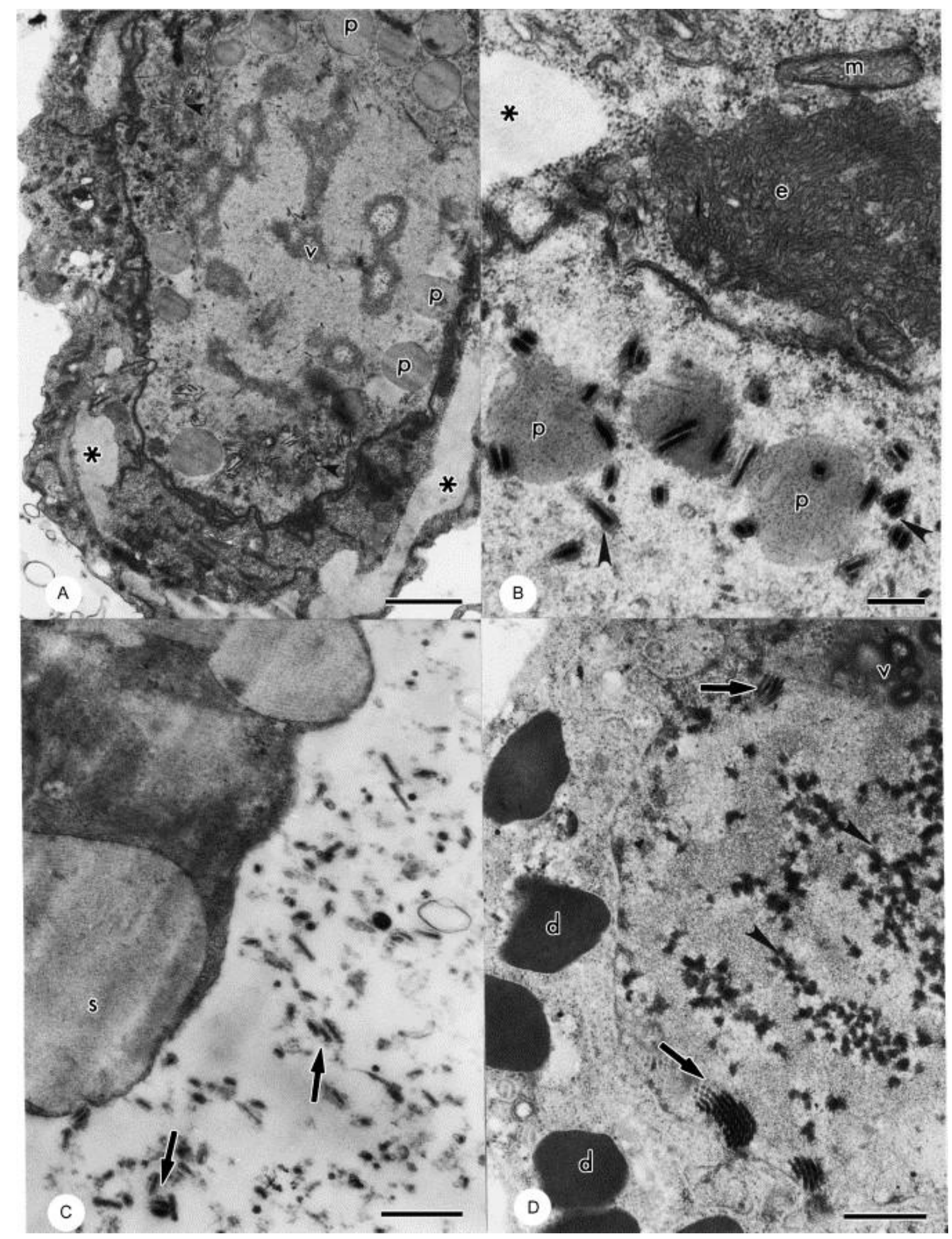

Fig. 5. Transmission electron micrographs of Anticarsia gemmatalis haemocytes $72 \mathrm{~h}$ p.i. with AgMNPV. (A) Plasmatocyte showing late infection events as mature virogenic stroma ( $v$ ), polyhedra (p) and extensive fibrillar aggregates (*). Arrowheads, virions envelopment. Bar $1 \mu \mathrm{m}$. (B) Not identified haemocyte presenting polyhedra $(p)$ assembling, where multiple enveloped virions (arrowheads) are involved by polyhedrin; e, endomembranes network; $\mathrm{m}$, mitochondria; fibrillar aggregate (*). Bar 0.5 $\mu \mathrm{m}$. (C) Free budded viruses (arrows) close to a spherulocyte (s). Bar $0.5 \mu \mathrm{m}$. (D) Infected granular haemocyte 2 presenting packed virions (arrows), dense aggregates (arrowheads), and membranous vesicles (v); d, dense granules. Bar $0.5 \mu \mathrm{m}$. 
Infected gh2 were observed at low frequency as compared to the other cell types, even at late times post-infection (Fig. 5D). Infected pr were not readily identifiable because of size alterations, which made these cells easily misinterpreted as pl.

Plasmatocytes (pl) were shown to be able to adjust their size and shape and phagocytose entire cells. Phagocytosed cells could present or not clear signs of infection (Fig. $6 \mathrm{~A}$ and $\mathrm{B})$.

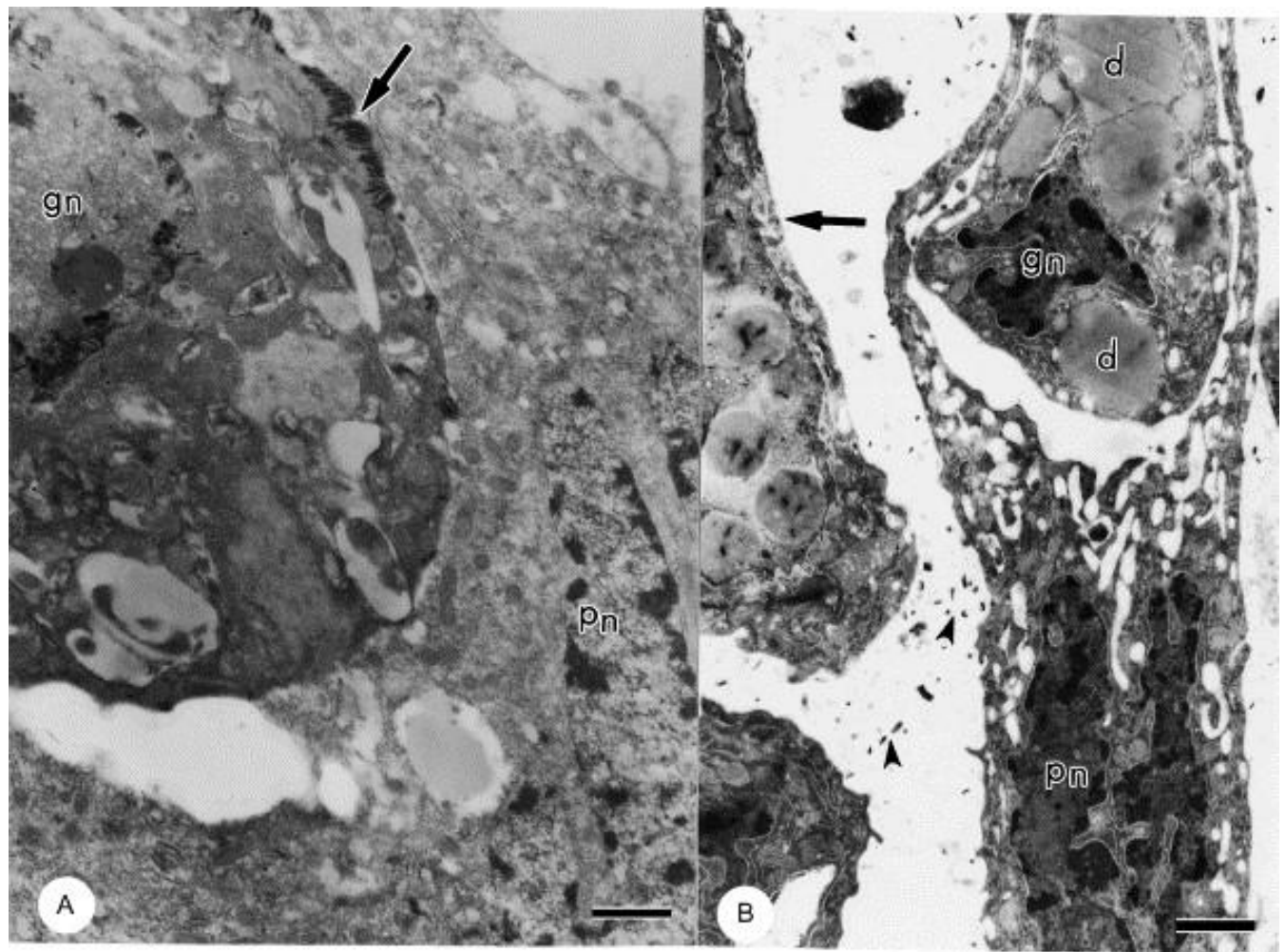

Fig. 6. Transmission electron micrographs of Anticarsia gemmatalis phagocytic plasmatocytes $72 \mathrm{~h} \mathrm{p.i.}$ with AgMNPV. (A) Infected granular haemocyte 1 engulfed by a plasmatocyte. Arrow, virions aligned at the gh1 surface; gn, gh1 nucleus; pn; pl nucleus. Bar $1 \mu \mathrm{m}$. (B) Apparently, non-infected granular haemocyte 2 engulfed by a plasmatocyte. Arrow, infected cell; arrowheads, free budded viruses; gn, gh2 nucleus; d, dense granules; pn, pl nucleus. Bar $0.5 \mu \mathrm{m}$.

\section{Discussion}

In this study, we demonstrated that A. gemmatalis larval haemocytes are susceptible to intrahaemocoelic infection by AgMNPV, leading to disease development and death of larvae around $96 \mathrm{~h}$ p.i. We have found that AgMNPV replicates in all of A. gemmatalis haemocytes types, which presented virions assembling, BVs cytoplasmic transport, budding, virogenic stroma, virions envelopment, fibrillar aggregates accumulation, and OBs assembling. This observation means that once the virus reaches haemolymph, it encounters an efficient media for replication and infection spread. 
For some lepidopteran larvae, haemocytes were shown to be resistant to AcMNPV infection. It is one factor that restricts AcMNPV infectivity in Spodoptera frugiperda ( Clark and Clem, 2002), and makes Helicoverpa zea and Manduca sexta semi-permissives for the same virus ( Washburn et al., 1996, Washburn et al., 2000 and Trudeau et al., 2001).

The sequence of cytopathological effects and viral morphogenesis events described here are in agreement with previous reports on A. gemmatalis culture cells infected with AgMNPV BVs ( Pombo et al., 1998); A. gemmatalis and Trichoplusia ni culture cells infected with the AgMNPV mutant vApAg ( Silveira et al., 1999) and midgut, tracheoblasts and haemocytes of A. gemmatalis larvae orally infected with AgMNPV OBs ( Matos et al., 1999).

An important difference is that symptoms appear earlier through intrahaemocoelic infection than oral infection. This is probably due to bypassing natural barriers and defences, such as midgut digestive juices, peritrophic membrane (Granados, 1980) and midgut cell sloughing (Hoover et al., 2000), are surpassed. In addition, a great number of free BVs (approximately $106 \mathrm{pfu}$ ) were promptly disposable for haemocytes infection.

Kislev et al. (1969) showed NPV replication events in haemocytes from Spodoptera litorallis after oral infection, intrahaemocoelic injection of polyhedra and of free ODVs. For the three modes of infection, pl were shown to be the major cell type for NPV replication. Cells classified as adipohaemocytes at that time, which presented clear characteristics of sph, did not become infected in these experiments. Phagocytosis of free-virus particles and polyhedra were also described mainly for pl.

AgMNPV infection generated clear phagocytic responses by $\mathrm{pl}$ and gh1. Both haemocytes types phagocytosed free virions, polyhedra and cell remnants. Unlike gh1, pl were able to phagocytose entire cells. This capability is compatible with larger pl dimensions, form variation and exuberant cytoplasmic extension when in contact with a surface.

Plasmatocytes (pl) and granular haemocytes type 1 (gh1) are reported as the only Lepidoptera larval haemocytes capable of adhering to foreign surfaces, being important for phagocytosis, nodulation and encapsulation (reviewed by Lavine and Strand, 2002). Together, pl and gh1 constitute around $60 \%$ of A. gemmatalis larval haemocytes ( Silveira et al., 2003), with similar occurrence being encountered in other lepidopterans ( Ribeiro et al., 1996 and Stettler et al., 1998), which indicates a great demand for the functions of these two cell types.

Together, phagocytosis and necrosis of infected haemocytes are clues for a putative recognition of these virus-infected cells as altered self, and the triggering of cytotoxic responses against them. Alternatively, necrosis might simply mean that virus is killing the cell. However, for cultivated cells infected with AgMNPV, membrane rupture and necrosis are 
generally observed only when the cells are full of polyhedra and fibrillar aggregates, and not before the total completion of the viral cycle, as frequently observed in this study.

The cytokine-like factor alloferon, described for the diperan Calliphora vicina, was shown to stimulate NK lymphocytes activity in vitro and to induce IFN production in mice, having antiviral and antitumoural capabilities (Chernysh et al., 2002). This report, together with our finding of a putative early death of baculovirus-infected haemocytes, suggest the possibility of a cytotoxic response against virus-infected cells in insects, in some way similar to the one triggered by $\mathrm{T}$ lymphocytes in mammals.

Until now, apoptosis is the best described antiviral response in insects (Clark and Clem, 2003b). Apoptosis reduces baculovirus replication in vitro, and AcMNPV mutants lacking the antiapoptotic gene p35 have reduced infectivity in S. frugiperda larvae if compared to the wild type virus (revised by Clem, 2001). More recently, apoptosis in vivo induced by baculovirus infection was demonstrated. Apoptosis was shown to be correlated with reduced viral propagation of AcMNPV in a non susceptible host ( Zhang et al., 2002) and with the reduced infectivity of an AcMNPV mutant lacking the antiapoptotic gene p35 in S. frugiperda ( Clark and Clem, 2003a).

Cellular immune responses described against baculoviruses comprises virus uptake in haemolymph, encapsulation and melanization of tracheal infection foci. It was demonstrated to be important for the circumvention of AcMNPV infection in H. zea and M. sexta, an organism-level strategy of resistance (Washburn et al., 1996, Washburn et al., 2000 and Trudeau et al., 2001).

Granular haemocytes type 1 (gh1) were shown to present numerous viral particles at their periphery, sometimes at long cytoplasmic projections, in such a way never described for any insect cell, in vivo or in culture. It is probable that AgMNPV finds in this cell type efficient machinery for replication and an important source of BVs for systemic infection.

The intense BVs protrusion was also observed in gh1 without visible signs of virus replication. But these cells had phagocytosed free polyhedra. We showed that probably phagocytosed polyhedra were dissolved into phagolysosomes, but some apparently intact virus particles remained. It is possible that ODVs resist to lysosomal digestion and escape from this organelle, probably utilizing membrane fusion. These free particles could be directed to the nucleus for virus replication or to the plasma membrane for budding. In this special case, at late times post-infection, ODVs could reinforce systemic spread of infection by infecting phagocytes. Further experiments are necessary to confirm putative ODVs lysosomal evasion, nuclear or surface directing and capability of haemocytes infection. 
Different from gh1, infected gh2 were scarcely found. Their low frequency (5-8\% of the haemocytes during 4th instar) (Silveira et al., 2003) could be a reasonable explanation, but we observed that even in late times post-infection, these cells were easily encountered and the majority did not show any signs of infection. It might mean that gh2 constitute an haemocyte type less susceptible to AgMNPV infection. This visible difference of susceptibility, added to the fact that gh2 did not present phagocytic behaviour, reinforce the separation of different types of granulocytes ( Brehélin and Zachary, 1986), which has been questioned in literature ( Gupta, 1991).

Despite the occurrence of phagocytosis and putative cytotoxic destruction of infected cells, our results show that, once AgMNPV BVs gain access to the haemolymph of $A$. gemmatalis larvae, it encounters an effective media for virus replication and systemic infection spread, maybe one of the factors that make this insect fully permissive to AgMNPV. This is a valuable finding since infection spread and death of larvae can also be achieved by intrahaemocoelic infection of baculovirus with minor involvement of haemocytes, as observed for the system AcMNPV×S. frugiperda ( Clark and Clem, 2002). Additional studies should be of interest to evaluate the relative importance of haemolymph for spread of AgMNPV infection, haemocytes behaviour and its interactions with the virus, using the natural route of infection, feeding the larvae on occlusion bodies.

\section{Acknowledgements}

We are grateful to Dr. M.E.B. Castro (Embrapa-Recursos Genéticos e Biotecnologia) and Dr. F. Moscardi (Embrapa-Soja) for supplying Anticarsia gemmatalis eggs and larvae. We also thank R. Machado for grammatical revision of the manuscript and the two anonymous referees for the comments and suggestions, that were crucial for the text improvement. This work was supported by CAPES, CNPq, FAP/DF, FINATEC and PRONEX.

\section{References}

Barrett, J.W., Brownwright, A.J., Primavera, M.J., Retnakaran, A., Palli, S.R., 1998. Concomitant primary infection of the midgut epithelial cells and the hemocytes of Trichoplusia ni by Autographa californica nucleopolyhedrovirus. Tissue Cell 30, 602-616.

Brehélin, M., Zachary, D., 1986. Insect haemocytes: a new classification to rule out the controversy. In: Brehélin, M. (Ed.), Immunity in Invertebrates: Cells, Molecules and Defense Reactions. Springer-Verlag, Berlin, pp. 36-48.

Castro, M.E.B., Ribeiro, B.M., 2001. Production of viral progeny in insect cells undergoing apoptosis induced by a mutant Anticarsia gemmatalis nucleopolyhedrovirus. Microbiol. Res. 156, 369-376. 
Chernysh, S., Kim, S.I., Bekker, G., Pleskach, V.A., Filatova, N.A., Anikin, V.B., Platonov, V.G., Bulet, P., 2002. Antiviral and antitumor peptides from insects. Proc. Natl. Acad. Sci. U.S.A. 99, 12628-12632.

Clark, T.E., Clem, R.J., 2002. Lack of involvement of haemocytes in the establishment and spread of infection in Spodoptera frugiperda larvae infected with the baculovirus Autographa californica M nucleopolyhedrovirus by intrahaemocolic injection. J. Gen. Virol. 83, 1565-1572.

Clark, T.E., Clem, R.J., 2003a. In vivo induction of apoptosis correlating with reduced infectivity during baculovirus infection. J. Virol. 77, 2227-2232.

Clark, T.E., Clem, R.J., 2003b. Insect defenses against virus infection: the role of apoptosis. Int. Rev. Immunol. 22, 401-424.

Clem, R.J., 2001. Baculoviruses and apoptosis: the good, the bad and the ugly. Cell Death Differ. 8, 137-143.

Granados, R.R., 1980. Infectivity and mode of action of baculoviruses. Biotechnol. Bioeng. 22, 1377-1405.

Granados, R.R., Lawler, K.A., 1981. In vivo pathway of Autographa californica baculovirus invasion and infection. Virology 108, 297-308.

Granados, R.R., Guoxun, L., Dersksen, A.C.G., McKenna, K.A., 1994. A new insect cell line from Trichoplusia ni (BTI-Tn-5B1-4) susceptible to Trichoplusia ni single enveloped nuclear polyhedrosis virus. J. Invert. Pathol. 64, 260-266.

Grasela, J.J., McIntosh, A.H., 1998. In vitro and in vivo host range of Anticarsia gemmatalis multiple nuclear polyhedrosis virus. In Vitro Cell Dev. Biol. Anim. 34, 79-83.

Gupta, A.P., 1991. Insect immunocytes and other hemocytes: roles in cellular and humoral immunity. In: Gupta, A.P. (Ed.), Immunology of Insects and Other Arthropods. CRC Press, Boca Raton, pp. 19-118.

Hoover, K., Washburn, J.O., Volkman, L.E., 2000. Midgut-based resistance of Heliothis virescens to baculovirus infection mediated by phytochemicals in cotton. J. Insect Physiol. 46, 999-1007.

Johnson, D.W., Maruniak, J.E., 1989. Physical map of Anticarsia gemmatalis nuclear polyhedrosis virus (AgMNPV-2) DNA. J. Gen. Virol. 70, 1877-1883.

Kislev, N., Harpaz, I., Zelcer, A., 1969. Electron-microscopic studies on haemocytes of the Egyptian conttonworm, Spodoptera litorallis (Boisduval) infected with a nuclear-polyhedrosis virus, as compared to noninfected hemocytes. II. Virus-infected hemocytes. J. Invert. Pathol. $14,245-257$.

Lavine, M.D., Strand, M.R., 2002. Insect hemocytes and their role in immunity. Insect Biochem. Mol. Biol. 32, 1295-1309.

Matos, T.G.T., Giugliano, L.G., Ribeiro, B.M., Báo, S.N., 1999. Structural and ultrastructural studies of Anticarsia gemmatalis midgut cells infected with the baculovirus $A$. gemmatalis nucleopolyhedrovirus. Int. J. Insect Morphol. Embriol. 28, 195-201. 
Moscardi, F., 1999. Assessment of the application of baculoviruses for control of lepidoptera. Annu. Rev. Entomol. 44, 257-289.

O’Reilly, D.R., Miller, L.K., Luckow, V.A., 1992. Baculovirus Expression Vectors. A Laboratory Manual. W.H. Freeman and Company, New York.

Pinedo, F.J.R., Moscardi, F., Luque, T., Olszewski, J.A., Ribeiro, B.M., 2003. Inactivation of the ecdysteroid UDP-glucosyltransferase (egt) gene of Anticarsia gemmatalis nucleopolyhedrovirus (AgMNPV) improves its virulence towards its insect host. Biol. Control 27, 336-344.

Pombo, V., Velloso, L.M., Ribeiro, B.M., Báo, S.N., 1998. Structural and ultrastructural changes during the infection of UFL-AG-286 cells with the baculovirus AgMNPV. J. Invert. Pathol. 72, 239-245.

Razuck, F.B., Ribeiro, B., Vargas, J.H., Wolff, J.L., Ribeiro, B.M., 2002. Characterization of the p10 gene region of Anticarsia gemmatalis nucleopolyhedrovirus. Virus Genes 24, 243-247.

Ribeiro, C., Simões, N., Brehélin, M., 1996. Insect immunity: the haemocytes of the armyworm Mythimna unipuncta (Lepidoptera: Noctuidae) and their role in defence reactions. In vivo and in vitro studies. J. Insect Physiol. 42, 815-822.

Ribeiro, B.M., Souza, M.L., Kitajima, E.W., 1998. Taxonomia, caracterização molecular e bioqu'ımica de v'ırus de insetos. In: Alves, S.B. (Ed.), Controle Microbiano de Insetos. FEALQ, Piracicaba, pp. 481-507.

Ribeiro, B.M., Gatti, C.D.C., Costa, M.H., Moscardi, F., Maruniak, J.E., Possee, R.D., Zanotto, P.M.A., 2001. Construction of a recombinant Anticarsia gemmatalis nucleopolyhedrovirus (AgMNPV-2D) harbouring the beta-galactosidase gene. Arch. Virol. 146, 1355-1367.

Rodrigues, J.C., Souza, M.L., O’Reilly, D.R., Velloso, L.M., Pinedo, F.J., Razuck, F.B., Ribeiro, B., Ribeiro, B.M., 2001. Characterization of the ecdysteroid UDP-glucosyltransferase (egt) gene of Anticarsia gemmatalis nucleopolyhedrovirus. Virus Genes 22, 103-112.

Sieburth, P.J., Maruniak, J.E., 1988. Susceptibility of an established cell line of Anticarsia gemmatalis (Lepdoptera: Noctuidae) to three nuclear polyhedrosis viruses. J. Invert. Pathol. 52, 453-458.

Silveira, E.B., Ribeiro, B.M., Báo, S.N., 1999. Morphological studies of apoptosis in insect cells infected with vApAg, an Anticarsia gemmatalis nucleopolyhedrovirus mutant. J. Submicrosc. Cytol. Pathol. 31, 543-554.

Silveira, E.B., Ribeiro, B.M., Báo, S.N., 2003. Characterization of larval haemocytes from the velvetbean caterpillar Anticarsia gemmatalis (Hübner) (Lepidoptera: Noctuidae). J. Submicrosc. Cytol. Pathol. 35, 129-139.

Stettler, P., Wyler, T., Pfister-Wilhelm, R., Lanzrein, B., 1998. Overview of parasitism associated effects on host haemocytes in larval parasitoids and comparison with effects of the egg-larval parasitoid Chelonus inanitus on its host Spodoptera littoralis. J. Insect Physiol. 44, 817-831.

Trudeau, D., Washburn, J., Volkman, L.E., 2001. Central role of haemocytes in Autographa californica M nucleopolyhedrosis pathogenesis in Heliothis virescens and Helicoverpa zea. J. Virol. 75, 996-1003. 
Volkman, L.E., Keddie, B.A., 1990. Nuclear polyhedrosis virus pathogenesis. Semin. Virol. 1, 249-256.

Washburn, J.O., Kirkpatrick, B.A., Volkman, L.E., 1995. Comparative pathogenesis of Autographa californica $\mathrm{M}$ nuclear polyhedrosis virus in larvae of Trichoplusia ni and Heliothis virescens. Virology 209, 561-568.

Washburn, J.O., Kirkpatrick, B.A., Volkman, L.E., 1996. Insect protection against viruses. Nature $383,767$.

Washburn, J.O., Haas-Stapleton, E.J., Tan, F.F., Beckage, N.E., Volkman, L.E., 2000. Co-infection of Manduca sexta larvae with polydnavirus from Cotesia congregata increases susceptibility to fatal infection by Autographa californica M nucleopolyhedrovirus. J. Insect Physiol. 46, 179190.

Williams, G.V., Faulkner, P., 1997. Cytological changes and viral morphogenesis during baculovirus infection. In: Miller, L.K. (Ed.), The Baculoviruses. Plenum Press, New York, pp. 61107.

Zhang, P., Yang, K., Da'ı, X., Pang, Y., Su, D., 2002. Infection of wildtype Autographa californica multicapsid nucleopolyhedrovirus induces in vivo apoptosis of Spodoptera litura larvae. J. Gen. Virol. 83, 3003-3011. 